\title{
Metacognition as scaffolding for the development of listening comprehension in a social MALL App
}

\section{La metacognición como andamiaje para el desarrollo de la comprensión oral en una App de MALL social}

\author{
Timothy Read \\ Elena Barcena \\ Universidad Nacional de Educación a Distancia, UNED (Spain)
}

\begin{abstract}
This article focuses on the role that metacognition can effectively play in the development of second language listening comprehension, and specifically, how a mobile app can be specified to this end. A social mobile assisted listening app, ANT (Audio News Trainer), is presented as a prototype for exploring the way in which students can be helped to use metacognition to improve relevant linguistic communicative competences. A study has been undertaken with students using ANT to explore the intricate nature of the listening comprehension development process and the main metacognitive strategies that can be successfully applied. Special attention is paid to the implicitly and explicitly applied metacognitive strategies within the app, and related social network, where follow-on activities were undertaken, the strategies in question being: focus (a conscious effort on the gradual development of individual skills), engagement (interest is enhanced when a learning activity is enjoyable/successful), interaction (since collective activities seem to enhance emotional and social involvement), reflection (upon what works and does not work for each individual), self-regulation (through data about the students' own progress and achievements), and attitude (here a further distinction is made between satisfaction, self-confidence and encouragement). The stages of engagement of a student with the app are explored in relation to the metacognitive strategy used and how they can contribute to the overall success of the learning experience. Finally, a reflection is made about how metacognitive strategies offer an effective way to compensate for the lack of teacher presence, support and guidance, on a medium/long term basis. However, although the study of the initial use of this social listening training app shows the potential for incorporating 'knowing about knowing' into mobile technology, it is suggested that future research is required to provide finer-grained insights into this process.
\end{abstract}

Keywords: language instruction; computer assisted language learning; listening comprehension; metacognition. 


\section{Resumen}

Este artículo trata acerca de la función que puede desempeñar eficazmente la metacognición en el desarrollo de la comprensión oral de segundas lenguas y, específicamente, cómo se puede crear una app móvil con este fin. Se presenta como prototipo una app de aprendizaje social asistido por móvil, de nombre ANT (Instructor de Noticias de Audio), con el fin de explorar el modo en que se puede asistir a los estudiantes para que empleen su capacidad metacognitiva y mejoren competencias lingüístico-comunicativas relevantes. Se ha llevado a cabo un estudio con estudiantes usando ANT para explorar la compleja naturaleza del proceso de desarrollo de la comprensión oral y las principales estrategias metacognitivas que pueden aplicarse satisfactoriamente. Se presta especial atención a las estrategias metacognitivas aplicadas implícita y explícitamente en la app y la red social relacionada, donde se realizan actividades subsiguientemente, siendo las estrategias en cuestión: foco (un esfuerzo consciente en el desarrollo gradual de habilidades individuales), compromiso (el interés crece cuando se disfruta y realiza con éxito una actividad), reflexión (sobre lo que funciona y no funciona para cada individuo), auto-regulación (a través de datos sobre el progreso y logros de los propios estudiantes) y actitud (en la que se aprecia una subdivisión entre la satisfacción, la confianza en uno mismo y el estímulo). Se exploran las etapas de compromiso de un estudiante con la app y como pueden contribuir al conjunto del éxito de la experiencia de aprendizaje. Finalmente, se realiza una reflexión sobre cómo las estrategias metacognitivas ofrecen un modo eficaz de compensar la falta de la presencia, el apoyo y la guía del profesor, a medio y largo plazo. Sin embargo, aunque el estudio del uso inicial de esta app para el desarrollo social de la comprensión auditiva muestra su potencial para incorporar 'conocimiento sobre conocimiento' en tecnología móvil, se sugiere la necesidad de contar con más investigación que permita una percepción más precisa de este proceso.

Palabras clave: enseñanza de lenguas; aprendizaje de lenguas asistido por ordenador; comprensión oral; metacognición.

Listening as a second language skill is well documented in the literature, where it is argued to be more than just perceiving meaning directly from sound1 (Anderson and Lynch, 1988; O’Malley, Chamot, \& Kupper, 1989; Underwood, 1989; Vandergrift, 1997; Gilakjani \& Ahmadi, 2011). As Vandergrift (2011) notes, listening comprehension occurs within milliseconds of hearing, and involves the interaction of different cognitive processes, such as access fluidity (relating knowledge from the language system to meaning) and attention (focusing and refocusing on what is being said in real time) (Segalowitz, 2007). Meaning in this case is argued to be an essentially constructivist process that includes both top-down (concept-driven) and bottom up processes (data-driven) (Gilakjani \& Ahmadi, 2011; Yamada et al., 2012). Furthermore, there is general consensus that the underlying mental processes that 
establish meaning combine different types of knowledge to what has been heard (Nunan, 1998), mostly linguistic knowledge (specifically, phonological [French, 2003]; lexical [Mecartty, 2000]; and also, but less so, grammatical (Field, 2008) and real world knowledge (Long, 1990; Brown, 2001; Rost, 2001; Gilakjani \& Ahmadi, 2011). Meaning as such might actually be interpreted in the sense of predicting what could be heard next based upon what has been heard, using knowledge that the listener already has in the form of schemata or other mental structures (Nunan, 1998). The exact relation between top-down and bottom-up processing is argued to depend on the nature of the listening task, the context, and the individual listener (Wu, 1998; Flowerdew \& Miller, 2005). Vandergrift (2011) argues that for this process to be successful, the coordination of a series of sensorial and mental processes is necessary.

For some time, teachers have tried to help students improve their listening comprehension in a second language by applying an essentially implicit behavioural approach, based upon practice and repetition, with increasingly more complex oral input and/or task conditions (Schmidt, 1992; DeKeyser, 2001; MacWhinney, 2001; Blasco, 2009). As researchers tried to improve this process and make the stages more explicit, more importance was given to specific strategies, especially those related to cognitive and metacognitive processes and their application in the listening process (Murphy, 1987; O’Malley, Chamot \& Kupper, 1989; Rost \& Ross, 1991; Bacon, 1992; Thompson \& Rubin, 1996; Buck, 2001; Goh, 2002; Vandergrift, 2007; Goh, 2008; Bozorgian, 2012). There is no consensus about the exact steps that a student should be encouraged to follow when training his/her listening comprehension. Vandergrift (2004, 2007), for example, argues for a five stage approach: planning/ processing, first verification (monitoring and planning), second verification (monitoring, problem solving, and evaluation), final verification (selective attention and monitoring), and reflection. Yokoyama (2005), however, outlines a seven stage approach: listening with a specific objective, predicting what will be heard next, listening while predicting, responding to what has been understood, trying to guess the meaning when input is not clear, verifying predictions and guesses, asking questions when necessary, and monitoring one's comprehension. In comparison, Flowerdew and Miller (2005) identify eight dimensions that play a role in the complex process of listening (individual, cross-cultural, social, affective, contextual, strategic, intertextual, and critical), which, while they are not direct stages that can be undertaken, they are argued to be factors that need to be included in successful listening comprehension.

Due to the lack of consensus on the exact steps that should be used in training listening comprehension, language teachers typically try to integrate both cognitive and metacognitive strategies that can be employed, as Grabe (2004) noted, before, during and after listening activities. What is clear, however, is that their use does improve listening comprehension. Furthermore, the authors of this article argue that metacognition is key in the listening comprehension development process and, 
as such, should be included both implicitly and explicitly in any second language learning framework.

\section{METACOGNITION AND LISTENING COMPREHENSION}

Flavell (1979) coined the term metacognition as "knowledge concerning one's own cognitive processes and products or anything related to them", which he further divided into three aspects: cognitive processes (both his/her own and those of others), information and resources about the current task, strategies which are relevant to the task at hand and any related goals. Vandergrift \& Goh (2012, p.5), when talking about the importance of metacognition in listening comprehension, define it to be "the ability of learners to control their thoughts and to regulate their own learning". Other authors, such as Davidson \& Sternberg (1998), support this position and argue that metacognitive knowledge enables the steps needed to solve problems to be represented explicitly, and therefore, facilitate their use in finding solutions.

Given the need to coordinate both top-down and bottom-up processes when undertaking listening comprehension, authors such as Rose \& Kasper (2001) and Vandergrift (2003) argue that learners benefit from developing metacognitive knowledge about the listening process and how, for example, background information can be used to form hypotheses about the content. Goh (2008) notes that successful listening depends upon this metacognitive awareness of the two different types of processes. Tsui \& Fullilove (1998) argue that such knowledge can compensate for incomplete bottom-up processing if the listener is familiar with what is being said. It can be argued, however, that the opposite is also true in that effective bottomup processing can compensate for a lack of knowledge about what is being listened to. In general, the self-regulation of cognitive processes, namely metacognition, has been noted consistently in the literature to be a characteristic shared by successful learners (for example, O’Malley \& Chamot, 1990; Goh, 2002; Vandergrift, 2003; Veenman et al., 2007). It is not surprising then that 'metacognitive instruction' is used to help students develop and facilitate the process of listening comprehension (e.g., Bozorgian, 2012).

In a related fashion, Mendelsohn (1994) had used the term 'strategy-based approach' to refer to the way in which listening strategies could be included into the classroom curriculum, thereby preparing students for such comprehension activities. He argued that the strategy instruction should be the 'spinal cord' around which the listening comprehension can be undertaken. According to him, this approach must train students how to listen, making use of the strategies that are effective, while moving away from those that are ineffective or even counter productive, such as, for example, mental translation or dictionary lookup. Authors such as Field (2001) and Vandergrift (2007) discuss elements of a pedagogical cycle that can be used by listeners to help develop the relevant top-down and bottom-up processes including 
planning and monitoring, and including the use of prior knowledge and reflection when problems in understanding arise.

Research has been undertaken on the use of metacognitive instruction in faceto-face (henceforth, F2F) learning contexts. Cross (2009) undertook an experiment with twenty Japanese advanced listening comprehension students over five lessons, finding that pre-test and post-test scores show that the less-skilled listeners improved across the lessons. Vandergrift and Tafaghodtari (2010) undertook a similar procedure for 106 beginner and lower-intermediate French students during a semester. Similarly, the pre-test and post-test results revieled that the less-skilled individuals improved more than the others. Similar results had also been obtained by Goh \& Taib (2006), so it would appear to be clear that for less experienced students, helping them improve their metacognition has a direct positive effect on listening comprehension.

Given the demand for online and distance learning in our modern society, where people are often too busy to attend F2F classes, computer-based approaches to language learning have gained popularity. Since the very first computers appeared, they have been used for teaching/learning purposes (Levy, 1997). As technology improved over time, the possibilities for using them also increased. Better graphics, audio characteristics, and the inclusion of CDROM and DVDs, etc., improved their applicability to language learning, giving rise to a whole approach to learning languages referred to as Computer Assisted Language Learning (or CALL). As technology and network connectivity improved, the size of computers continued to reduce, from large mainframes to mini-computers, then to desktop systems, and finally to portable or laptop machines. These opened up the possibility for students to carry their language learning programs and resources with them. Although these machines were smaller, they were still too heavy to limit their use in most everyday situations. In parallel, the increase in the sophistication and functionality of mobile phones has led to the incorporation of some of the functions of computers and they have even become known in themselves as smartphones or a kind of handheld computer. The possibilities for using such devices for learning in general and language learning in particular (referred to as ML and MALL respectively), has been amply documented in the literature (e.g., Sharples, 2000; Traxler, 2005; Nash, 2007; Kukulska-Hulme, 2009; Read et al., in press). As well as their computing power, which can be used to run small programs, or apps, reproduce multimedia recordings, etc., they are also equipped with a series of sensors that enable local data to be recorded (e.g., photos, audio, geolocation), which adds to their value as learning tools. Furthermore, their connection to Internet enables these devices to be used to increase learning opportunities, for which it is commonly said that they provide 'anytime, anywhere' learning possibilities. Finally, given the reduction in cost of these devices, it is ever more common for students to own their own mobile devices, and therefore, want to use them for their learning. The expectancy that this 
has generated in educators has been reflected in the term coined by Ballagas, et al. (2004), namely Bring Your Own Device (or BYOD).

Data has been presented in the literature showing how the use of MALL in second language listening comprehension can be effective (e.g., Azar \& Nasirib, 2014, Read et al., in press) and can also motivate the students to continue practising (partly because of the portability and the immediacy they offer to students; Norbrook \& Scott, 2003), beyond the scope of limited experiments (Barcena et al., 2013). While students use this technology as directed by their teachers, they are not autonomous and tend to stop using the technology once a given course or study period is over. Furthermore, the most commonly used MALL technology, that of podcasting, has not had metacognitive strategies directly included, but relies on the assistance provided by language teachers which, as the authors of this article argue, limits their value for distance learning students.

Within the podcasting literature, some research has been done on the relation of metacognition to listening, however. Rahimi (2012) presented a Metacognitive Awareness Listening Questionnaire (MALQ) questionnaire to 140 second language students to assess their knowledge of listening strategies. The questionnaire focussed on five areas: planning and evaluation, attention, personal knowledge, use of mental translation, and problem solving. The students also answered a further questionnaire on the use of podcasting as part of their second language studies. The results of the both questionnaires showed a correlation between podcasting and the students' awareness of metacognitive listening strategies. Alm (2013) went further by using Vandergrift \& Goh's (2012) metacognitive approach for podcast-based listening comprehension training. The study was carried out on 28 intermediate level German students who used podcasts for one semester. The students documented their experience with them writing a review and, at the end of the study, undertook a questionnaire on their experience. The results pointed out the use of metacognition in the students' behaviour, which was also evident in what they wrote about the recordings.

In the distance-learning context, where there is typically very little contact between the students and the teaching team, so it was decided that the metacognitive knowledge and learning strategies necessary for the students to undertake listening comprehension effectively would actually be included in the app and related activity instructions, and not provided a priori by the teaching team. This was the case because the inclusion of such knowledge and strategies in the general documentation that distance-learning students receive as part of their course, is not very effective since they typically do not read it or pass sufficient attention. 


\section{THE AUDIO NEWS TRAINER APP}

A MALL app (ANT, the Audio News Trainer; Barcena et al., 2013; Read et al., in press) was developed to apply the generally accepted principles of teaching listening comprehension (in the literature) in a face-to-face environment for students at a distance learning university, UNED (where contact between teachers and students is rare). Previous research by the authors and their experience in learning a language in distance education suggested that such an app could be more effective than directly listening to news recordings from Internet as explained further on. ANT uses audio news recordings to develop oral and, to a lesser extent, written competences from their mobile phone or tablet. The news recordings came from sources that were classified into three levels of difficulty (easy, medium and difficult), depending upon the newsreader's speech speed and accent. When the students started the app, before accessing the news recordings, they were presented with different guidelines about how they should use it and undertake the listening task.

As the students undertook this task, they were requested to focus carefully on the different aspects of what they were hearing, trying to select and connect relevant information. When the recording finished, before answering any questions or writing a summary in the app, they were encouraged to reflect upon what they had heard and understood and, if necessary, go back and listen again to the parts that had caused them problems. The selection of news recordings for this app and listening comprehension training in general can be seen to be beneficial for the students since they are about different types of events that are happening/relevant at the moment. This represents a source of up to date information for the students and it is arguably easier for them to understand than other text types, because even though the news stories are in English, they are probably relatively familiar with the topics being discussed. These days, with the number of formats in which news are available, i.e., textual publications like newspapers, magazines, radio, TV and Internet, it is difficult not to be aware of the main events taking place in the world!

The app contains a series of basic closed questions about the conditions in which the students have been listening to a given news recording and whether the students feel that they have understood what they have been listening to. A related question provides an opportunity for the students to actually pause, reflect upon what they have just heard, and then make a judgment about their performance. After having listened to a news recording and answered the closed questions, the students are expected to write a brief summary of what they have understood (enabling them to actively process the information and think about the key parts that they then have to write in the app). When s/he has finished and clicks the finish button to store the results of the questions and go back to select another question, the textual summary is posted automatically to Facebook, as can be seen in figure 1, as the seed for subsequent collaborative activities. 
Figure 1. Example ANT post to Facebook page

The ANT App Community
Publicada por Scm-Ant Demo [?] 9 de enero
sn110 just listened to Today $9 / 1 / 2015$ Today: Why are some hospitals
struggling to cope with patient numbers?
What I have understood: There are several factor which affect the problem
hospitals have with the number of patients. On one hand, the broadening of
the coverage of telephone 111 ; on the other hand, the increase on the rate of
patients they consider have to be treated early or sent and ambulance for.
There's also a lack of emergency doctors because of the extreme pressure
they're under, which leads them to chose other specialties or emigrate, for
example to Australia.

In this final part of the learning scenario, the students leave the ANT app and go to the ANT Facebook page to see their post, similar posts by other students on the same news recording and any other posts that might be there. Once a student is on the ANT Facebook page and has found other students' summaries to the same news that $\mathrm{s} /$ he has listened to, $\mathrm{s} /$ he has two options: firstly, if another student's summary has the same interpretation, then the student is requested to click on the "Like" button to show his/her agreement. If this is not the case, then the student can comment on the summary stating what $\mathrm{s} /$ he feels is wrong or ask a question. The objective here is to spark off student debate about what they have understood, which provides a further opportunity to reflect upon what they have heard (they can even go back and listen to the recording again if they want to) and a chance to actually focus on parts of the recording that were not clear previously. Finally, once they have done this, if there is still a lack of consensus, other online materials, resources, social media, etc., can be used to find arguments in favour of one's interpretation.

\section{LEARNING SCENARIO AND RESEARCH DESIGN}

In the present research, an experimental scenario was prepared to explore the effectiveness of the way in which metacognitive scaffolding has been included in the app and related functionality. Forty five students on an English language access course at the distance learning university UNED volunteered to take part in the study. Given the eclectic nature of the students on the course, which is mandatory for all future students at the university, the students' (self-reported) language capability ranged from $\mathrm{A} 2$ to $\mathrm{C} 1$ (following the levels of the Common European Framework of Reference for Languages; Council of Europe, 2001). The diversity of the student population made assessing improvements in listening via pre- and post- tests impossible. A series of five research questions were raised about the way in which 
the students' metacognitive skills develop as a result of using ANT, and how it helps them improve their listening comprehension:

1. Have the students developed awareness of their own strengths and weaknesses?

2. Are the students more aware of what they have to do to improve their skills in terms of tasks and strategies?

3. Do the students listen in a more structured way?

4. Does the use of social media help them become more self-regulated?

5. Are the students aware that certain external factors make listening harder?

The data needed to help answer these question came from four sources, following a mixed-method approach (Robson, 2002). Firstly, a pre-questionnaire was given to the students as part of their registration process to take part in the study, where questions were used to obtain an idea of the knowledge they had about metacognitive strategies that they might use during listening comprehension, and where, in fact, they might use them advantageously. Secondly, all interactions between the students and the app were logged on the project server. Such interactions included the recordings that they had listened to, how many times they had repeated any given recording, how long they had spent listening, etc. The answers to the closed questions that the app provides for them to answer at the end of each recording were also logged on the server. Thirdly, all the interactions on the ANT Facebook page (either directly from the app or from direct student interventions) were contained in the data model embedded in the page and after the experimental period was over, was extracted by the authors to be used for analysis. Fourthly and finally, a postquestionnaire was given to the students to provide data that complemented what had already been obtained and that would provide insights necessary for answering the research questions. The design and characteristics of the questionnaires were established following Cohen et al. (2007), to maximize data retrieval and their correlation with other results.

When structuring the learning scenario and the way in which the app would help the students, four factors were taken into account regarding process, complexity, length and personalization:

- The students need to be aware of the learning process that they should follow. They should prepare for the activity, try to remove distracting objects, have a receptive attitude and be prepared to modify (aspects of) preconceived ideas. According to their level, they should change the listening focus from most repeated and emphasized words to specific details. When appropriate, note taking can be used to write down identify words in the same order as they are heard. Finally, repetition can be useful by pausing and going back to hearing specific parts of the recording again. 
- The complexity of the learning activity is important and must be challenging enough for progress to occur but also simple enough in order not to increase the students' anxiety levels and decrease their motivation.

- The length of the listening activity must be short (and self-contained) to enable students to maintain their attention and be able to cope with the attentional/ cognitive effort required.

- Personalized learning can potentiate progress in two senses: firstly, they must be able to work their audio skills at their own level and pace, and the learning goal must be comfortably achievable for effective progress. Secondly, the student must be able to use scaffolding to adapt the activity to his/her level and learning style.

\section{QUALITATIVE RESULTS ANALYSIS AND DISCUSSION}

As has been noted in the previous section, the data available after the experimental period that can be used to answer the research question come from four sources and combine qualitative and quantitative data. Work is currently being done by the authors to undertake a low-level quantitative analysis of this very large body of data. However, for the purposes of this article, a higher-lever qualitative analysis has been undertaken that combines a comparison of the results from the pre- and post-questionnaires with the logged data both from the project server and the Facebook app page. For example, to detect how behavior has changed throughout the experimental period, comparisons were made between recordings listened to at the beginning, in the middle and at the end of the period. Hence, this type of essentially qualitative analysis of the data obtained in this study using ANT gave rise to a series of observations about the development of the students' metacognition, listening strategies, and their ability to understand the news recordings heard, which are reported here.

The first research question regarded the way in which the students developed awareness of their own strengths and weaknesses (related to the general skill of listening) during the use of the app, when listening, and the way in which they are capable of identifying the difficulties encountered. This is arguably an important source of information for them, since knowing what their weaknesses are can help them compensate for them and use appropriate strategies to overcome them. Between sessions, students reported having actually reflected upon the difficulties they had experienced and decided that they needed to be more attentive to strategies recommended in the app for the problems than they actually had. This development of awareness is evident in the results for lower-level students. However, for higherlevel students, there was not such a difference between the two questionnaires, arguably showing that they were more self-regulated. 
This difference in the first question does not imply that there would be such a clear difference in the second one. Here, the question was about the students' awareness of what strategies are available to them to improve their skills. The second question is a follow on from the first one, since it relates self-diagnosis to strategic selection of relevant solutions. It is assumed that pro-active students are more likely to understand this relation and be able to make the correct choice, asking for help if necessary. Furthermore, of the strategies presented in the app, apart from repetition and reflection, the most popular metacognitive strategy used was that of focusedlistening, i.e., listening while concentrating on particular types of information (who?, where?, when?, etc.). This was reported to help them filter the information and, after listening to a given recording several times, provide a more complete understanding of the content of the recording. Regarding the actual internalization of the different strategic elements to develop a 'listening recipe' that could be used whenever an opportunity presented itself, an essentially three-phase approach was reported: preparation by thinking about the topic to be listened to; focusing on, selecting and connecting relevant key information that appeared in the recording; and checking what had been understood by going to the social media app page. The students identified the generation of a summary for Facebook as an effective mechanism for two reasons: firstly, it caused them to take the listening comprehension 'more seriously', since they would publish what they had understood, therefore, having to think more carefully about it; and secondly, the actual feedback of their peers about their own summaries was reinforcing and helped them check what they thought they had understood.

Another aspect of metacognition when learning to listen to a second language, namely that of realizing that one has an incomplete mental representation of the audio, and hence require repetition, was identified in the students' behavior, since with relative ease a student could, with a single finger swipe, move backwards in the recording and listen to a given fragment as many times as required. In a related fashion, when a student was unable to understand a given recording (or at least part of it), being able to go to the social network and see other peoples' summaries was reported as being very helpful. It was also noted that sometimes just reading a small part of a summary on the Facebook page was sufficient to help with understanding. In this case the students in question developed a cyclic approach/strategy to listening where, after initially having difficulties trying to understand a recording, they would go to read someone else's summary, and then go back and try again. Furthermore, the answers from the questionnaires showed that regardless of the students' listening level, they noted that the use of the app together with its documentation and associated collaborative activities had helped them correlate their difficulties with appropriate (metacognitive) strategies that could be used to compensate for them. The lack of difference here presumably reflects the way that higher-level students had undertaken listening activities previously with little if any help and no explicit documented strategies to hand. In almost all cases, these students reported 
having listened to audio under their own initiative, on the radio or via Internet. Furthermore, as well as the answers to the questionnaires, the data logged from the app and the Facebook page showed no appreciable difference between the behaviour of different level students and evidence for how they regulated their listening using the strategies provided.

The third question highlights the importance of self-imposed structure when undertaking the listening comprehension. An important part of the structuring process was identified to take part during the preparation phase. Students typically reported that the title of a given news recording actually helped them to contextualize what they were going to listen to and be able to remember relevant background knowledge and vocabulary before starting to listen. However, in some cases, for less experienced students, this actually worked against them, since seeing that a recording was going to focus on something that they knew very little about actually made them anxious and, therefore, arguably hindered their listening process. Interestingly, even though it would have been very easy in these cases for students to actually use the Web browsers or other social media tools on their smartphones or tablets to search for background information that would have made the listening activity easier, they never did so. The questionnaire data clearly shows that the students believe that they undertake their listening activities in a more structured way than they did before starting to use the app. More research is needed to actually be able to conclude if this is a permanent change that could be detected away from the app, where the relevant cues are always available.

The fourth question about the role the social media in facilitating self-regulation can be answered, both in terms of the ratio of 'Likes' and comments to listened news recordings, and also the importance given to their use by the students in the questionnaires. This question relates to the presence of the metacognitive scaffolding in the social media activities (which could be explicit if additional instructions were added to the Facebook page. However, in this study, this was not the case and was also seen by the research team to be unnecessary). This scaffolding was also present in the actual app interface, implicit in that students had to reflect before undertaking the written summary, and explicit in the instructions on how listening should be undertaken. Furthermore, the authors argue that actually knowing that they will have to write a summary a priori also motivates them to listen more carefully, since not only do they have to write the summary but it will be also seen and read by their peers.

The fifth and final question explores the students' ability to identify the characteristics of the news recordings and the listening environment that cause them most difficulty, as an important step toward adopting suitable listening strategies. This question can be answered in terms of the closed questions present in the app, which specifically targeted this issue. Furthermore, the data logged showed that, with practice, the student became essentially better at identifying these factors and acting accordingly. The main factors predicted by the authors and confirmed by the 
students include the speaker's accent, the speed of locution, background noise, the familiarity of the topic, and the technical nature of the vocabulary being used (in this order). Students were advised to gradually expose themselves in a controlled manner to harder conditions, which was validated by the data logged. In the specific case of background noise, the students were advised to use the app in progressively noisier environments, like on the streets, in public transport, etc., and not to 'compensate' by having artificially high and potentially unhealthy high volume levels.

In terms of the app itself, the data logged showed that the instructions and strategies were checked by the students and also applied, at least as far as can be identified by repetitions, the periodicity of the preparation of the summaries, etc. Students would typically click through to the listening page and pause before starting the recording. After having listened to it (one or more times), they would answer the closed questions relatively quickly and then pause again before attempting to write the summary of the news recording for Facebook. Most students would then immediately go there (as far as it is possible to discern from the social network data logging), probably from the same mobile device, to look for summaries produced by other people and click 'Like' to show agreement or comment on them.

\section{CONCLUSIONS}

In this article some preliminary results are presented about the effectiveness of a social MALL app, ANT, to scaffold the development of metacognition when learning to develop listening comprehension in a distance-learning context. ANT implicitly and explicitly presents students with metacognitive strategies for listening comprehension to assist them in their learning process during and beyond the use of this software, and has been argued to offer an effective way to compensate for the lack of teacher presence, support and guidance on a medium/long term basis. Although this study of its initial use shows the potential of incorporating 'knowing about knowing' into mobile listening technology, future research is required to provide finer-grained insights into this process.

ANT has been designed to provide students with three advantages over directly listening to news recordings from Internet, either by using the Web browser on their smartphones or by using a podcast service that automatically makes the recordings available using a subscription-based mechanism. Firstly, as noted previously, three different difficulty levels of recordings are provided so that the students can attempt harder material as they progress and develop better listening skills. Secondly, the interface of the app has been developed following carefully selected pedagogic guidelines to enhance self-regulation and metacognition since, as has been noted previously, for their relevance in adult second language learning. Thirdly and finally, the way students can work collaboratively afterwards with other users to scaffold and refine what they think they have understood after listening to a recording, following a constructivist approach (McBride, 2009). This can be said to be a scaffolded 
process, since as the students progress and their listening competences improve, the support they require initially will gradually cease to be necessary, as they internalise the processes that they use to actually understand what they have heard.

It should be noted that, as reported in previous studies in the literature, students with self-reported lower levels of listening competences made more explicit use of the metacognitive strategies and scaffolding present in the app than their more advanced peers. However, this result needs to be treated with care, because all the students had to use some of the strategies due to the structure of the questions and activities. The difference between the former and latter students is that, since the notion of structuring listening itself was new to them, they did it in a more controlled and explicit way and were, therefore, more aware of the value of this aspect of their learning. The latter students, since they had more experience of second language listening per se, arguably also used some of the metacognitive strategies, but were less aware of doing so since the process was arguably more automatic for them. Furthermore, even though the latter students were not aware of actually using the strategies explicitly, if, as is arguably the case, they had internalized some of them, then it is to be expected that they were not 'conscious' of having done so.

The main limitation of the current version of ANT is the way in which the comprehension activity is structured in that the app directly requests students to summarise what they have understood from listening to a given audio news item. The results obtained are typically mechanical and do not reflect any 'emotional identification' by the students with the subject matter, which would arguably reinforce subsequent interaction in the social media, thereby promoting further learning. If the students were given more freedom to write about any aspect of the audio that they had found interesting, then more meaningful interaction might be subsequently produced. This remains a question for further work.

\section{NOTES}

1. The work presented in this article has been funded by the Spanish Ministry of Science and Innovation (ref. no. FFI 2011-29829).

\section{REFERENCES}

Alm, A. (2013). Extensive listening 2.0 with foreign language podcasts. Innovation in Language Learning and Teaching, 7 (3), 266-280.

Anderson, A., \& Lynch, T. (1988). Listening. Oxford: Oxford University Press.
Azar, A. S., \& Nasiri, H. (2014). Learners' Attitudes toward the Effectiveness of Mobile Assisted Language Learning (MALL) in L2 Listening Comprehension. Procedia-Social and Behavioral Sciences, 98, 1836-1843. 
Bacon, S. M. (1992). Phases of listening to authentic input in Spanish: A descriptive study. Foreign Language Annals, 25 (4), 317-334.

Ballagas, R., Rohs, M., Sheridan, J. G., \& Borchers, J. (2004). BYOD: Bring your own device. In Proceedings of the Workshop on Ubiquitous Display Environments, Ubicomp.

Barcena, E., Read, T., Arús, J., Pareja, A., Rodrigo, C., Martin-Monje, E., Pomposo, L., Rodríguez, P., \& Calle, C. (2013). Mobile Assisted Language Learning for professionals: integrating learning into the daily routines. In Proceedings of EUROCALL'13. University of Evora (Portugal).

Blasco Mayor, M. J. (2009). CALLenhanced L2 listening skills - aiming for automatization in a multimedia environment. Indian Journal of Applied Linguistics, 35 (1), 107-120.

Bozorgian, H. (2012). Metacognitive Instruction Does Improve Listening Comprehension. In International Scholarly Research Network ISRN Education.

Brown, E. (2001). Mobile learning explorations at the Stanford Learning Lab. Speaking of Computers, 55 .

Buck, G. (2001). Assessing listening. Cambridge: Cambridge University Press.

Cohen, L., Manion, L., \& Morrison, K. (2007). Research Methods in Education. London: Routledge.

Council of Europe. (2001). Common European Framework of Reference for Languages: Learning, Teaching, Assessment [online]. Cambridge: Cambridge University Press.

Cross, J. (2009). Effects of listening strategy instruction on news videotext comprehension. Language Teaching Research, 13 (2), 151-176.

Davidson, J. E., \& Sternberg, R. J. (1998). Smart problem solving: How metacognition helps. In D. J. Hacker,
J. Dunlosky \& A. C. Graesser (Eds.), Metacognition in educational theory and practice, (47-68). Mahwah, NJ: Lawrence Erlbaum Associates.

DeKeyser, R. M. (2001). Automaticity and automatization. In P. Robinson (Ed.), Cognition and second language instruction, (125-151). New York: Cambridge University Press.

Field, J. (2001). Finding one's way in the fog: Listening strategies and secondlanguage learners. Modern English Teacher, 9, 29-34.

Field, J. (2008). Bricks or mortar: Which parts of the input does a second language listener rely on? TESOL Quarterly, 42, 411-432.

Flavell, J. H. (1979). Metacognition and cognitive monitoring: A new area of cognitive-developmental inquiry. American Psychologist, 34, 906-911.

Flowerdew, J., \& Miller, L. (2005). Second language listening: Theory and practice. New York: Cambridge University Press.

French, L. (2003). Phonological working memory and L2 acquisition: A developmental study of Quebec francophone children learning English. Unpublished PhD dissertation. Université Laval, Canada.

Gilakjani, A. P., \& Ahmadi, M. R. (2011). A study of factors affecting EFL learners' English listening comprehension and the strategies for improvement. Journal of Language Teaching and Research, 2 (5), 977-988.

Goh, C. (2002). Exploring listening comprehension tactics and their interaction patterns. System, 30, 185206.

Goh, C., \& Taib, Y. (2006). Metacognitive instruction in listening for young learners. ELT Journal, 60, 222-232.

Goh, C. (2008). Metacognitive instruction for second language listening development: Theory, practice and research 
implications. RELC Journal, 39, 188213.

Grabe, W. (2004). Research on teaching reading. Annual Review of Applied Linguistics, 24, 44-69.

Kukulska-Hulme, A. (2009). Will mobile learning change language learning? ReCALL, 21 (2), 157-165.

Levy M. (1997). CALL: context and conceptualisation, Oxford: Oxford University Press.

Long, D. R. (1990). What you don't know can't help you. Studies in Second Language Acquisition, 12, 65-80.

MacWhinney, B. (2001).The competition model: the input, the context, and the brain. In P. Robinson (Ed.), Cognition and second language instruction (6990). Cambridge: Cambridge University Press.

Mecartty, F. (2000). Lexical and grammatical knowledge in reading and listening comprehension by foreign language learners of Spanish. Applied Language Learning, 11, 323-348.

McBride, K. (2009). Social networking sites in foreign language classes: Opportunities for re-creation. In L. Lomicka \& G. Lord (Eds.), The next generation: Social networking and online collaboration in foreign language learning. (35-58). San Marcos, TX: CALICO.

Mendelsohn, D. (1994). Learning to listen: A strategy-based approach for the second-language learner. San Diego, CA: Dominie.

Murphy, J. M. (1987). The listening strategies of English as a second language college students. Research \& Teaching in Developmental Education, 4 (1), 27-46.

Nash, S. S. (2007). Mobile learning, cognitive architecture and the study of literature. Issues in Informing Science and Information Technology (IISIT), 4, 811818.

Norbrook, H., \& Scott, P. (2003). Motivation in mobile modern foreign language learning. In Procedings of mLearn 2003, (pp. 50-51).

Nunan, D. (1998). Approaches to Teaching Listening in the Language Classroom. Paper presented at the Korea TESOL Conference, Seoul.

O’Malley, J. M., Chamot, A. U., \& Küpper, L. (1989). Listening Comprehension Strategies in Second Language Acquisition, Applied Linguistics, 1O, 418-37.

O’Malley, J. M., \& Chamot, A. U. (1990). Learning strategies in second language acquisition. Cambridge: Cambridge University Press.

Read, T., Barcena, E., \& Kukulska-Hulme, A. (in press). Exploring the application of a conceptual framework in a social MALL app. In A. Pareja, C. Calle \& P. RodríguezArancón (Eds.), New Perspectives on Teaching and Working with Languages in the Digital Era. London: Macmillan.

Robson, C. (2002). Real World Research: A Resource for Social Scientists and Practitioner-Researchers. Oxford: Blackwell Publishing.

Rose, K. R., \& Kasper, G. (Eds.). (2001). Pragmatics in language teaching. Cambridge: Cambridge University Press.

Rost, M., \& Ross, S. (1991). Learner strategies in interaction: Typology and teachability. Language Learning, 41, 235-273.

Rost, M. (2001). Listening in action. New York: Prentice Hall.

Segalowitz, N. (2003). Automaticity and Second Language. In C. Doughty \& M. Long (Eds.), The Handbook of Second Language Acquisition. (382-408). Oxford: Blackwell.

Sharples, M. (2000). The design of personal mobile technologies for lifelong learning. Computers \& Education, 34 (3), 177-193.

Schmidt, R. (1992). Psychological mechanisms underlying second language fluency. Studies in Second Language Adquisition, 14, 357-385. 
Thompson, I., \& Rubin, J. (1996). Can strategy instruction improve listening comprehension? Foreign Language Annals, 29 (3), 331-342.

Traxler, J. (2009). Current state of mobile learning. In M. Ally (Ed.), Mobile Learning Transforming the Delivery of Education and Training, (9-24). Athabasca: AU Press.

Tsui, A., \& Fullilove, J. (1998). Bottom-up or top-down processing as a discrimination of L2 listening performance. Applied Linguistics, 19, 432-451.

Underwood, M. (1989). Teaching Listening. New York: Longman.

Vandergrift, L. (1997). The strategies of second language (French) listeners: A Descriptive Study, Foreign Language Annals, 30, 387-409.

Vandergrift, L. (2002). It Was Nice to See that our Predictions Were Right: Developing Metacognition in L2 Listening Comprehension, Canadian Modern Language Review, 58, 556-75.

Vandergrift, L. (2003). From Prediction through Reflection: Guiding Students through the Process of L2 Listening, Canadian Modern Language Review, $59,425-40$.

Vandergrift, L. (2007). Recent developments in second and foreign language listening comprehension research. Language Teaching, 4O, 191-210.

Vandergrift, L., \& Tafaghodtari, M. H. (2010). Teaching students how to listen does make a difference: An empirical study. Language Learning, 6o, 470-497. Vandergrift, L. (2011). Second Language Listening. Handbook of Research in Second Language Teaching and Learning, 2, 455.

Vandergrift, L., \& Goh, C. (2012). Teaching and learning second language listening: Metacognition in Action. UK: Taylor \& Francis.

Veenman, M., Van Hout-Wolters, B., \& Afflerbach, P. (2006). Metacognition and learning: conceptual and methodological considerations. Metacognition and Learning, 1, 3-14.

Wu, Y. (1998). What do tests of listening comprehension test? A retrospection study of EFL test-takers performing a multiple-choice task. Language Testing, 15, 21-44.

YaMada, M., KitaMura, S., Shimada, N., Utashiro, T., Shigeta, K., Yamaguchi, E., Harrison, R., Yamuchi, Y., \& Nakahara, J. (2012). Development and Evaluation of English Listening Study Materials for Business People Who Use Mobile Devices: A Case Study. CALICO Journal, 29 (1), 44-66.

Yokoyama, N. (2005). "Katei” jushi no chokai shidou no kouka: Taimen-bamen ni okeru chokai katei no bunseki kara [The effects of process-oriented listening instruction: An analysis of comprehension process in an interactive setting]. Acquisition of Japanese as a Second Language, 8, 44-63.

\section{ACADEMIC AND PROFESSIONAL PROFILE OF THE AUTHORS}

Timothy Read is a senior lecturer at UNED. He has held several positions in the university government there. He is the cofounder of the ATLAS research group and has directed national and international funded projects on applying TIC to LSP. He is currently working in the area of MALL and Language MOOCs. He has also been a member of diverse scientific committees and has collaborated as an evaluator of national and international research project proposals.

E-mail: tread@lsi.uned.es 


\section{DIRECCIÓN DEL AUTOR}

Dpto. de Lenguajes y Sistemas Informáticos

ETSI Informática - UNED

C./ Juan del Rosal 16

28040

Madrid, Spain

Elena Barcena is an associate professor at UNED. She is the Director of the Doctorate Program in ICT for Language Teaching and Processing and also the Masters in English for Specific Purposes. She is the Director of the ATLAS (Applying Technology to Languages) research group, where she currently works on mobile assisted language learning and massive open online courses.

E-mail: mbarcena@flog.uned.es

\section{DIRECCIÓN DE LA AUTORA}

Dpto. de Filologías Extranjeras y sus Lingüísticas

Facultad de Filología

UNED

$\mathrm{P}^{\circ}$ Senda del Rey 7

28040

Madrid, Spain

Fecha de recepción del artículo: 18/06/2015

Fecha de aceptación del artículo: 16/09/2015

\section{Como citar este artículo:}

Read, T., y Barcena, E. (2016). Metacognition as scaffolding for the development of listening comprehension in a social MALL App. RIED. Revista Iberoamericana de Educación a Distancia, 19 (1), 103-120. doi: http://dx.doi.org/10.5944/ ried.19.1.14835 